\title{
Investigation on protalus ramparts in the Swiss Alps
}

\author{
C. Scapozza \\ Institute of Earth Sciences (IST), University of Applied Sciences and Arts of Southern Switzerland (SUPSI), \\ Campus Trevano, 6952 Canobbio, Switzerland \\ Correspondence to: C. Scapozza (cristian.scapozza@supsi.ch)
}

Received: 8 July 2014 - Revised: 27 November 2014 - Accepted: 27 March 2015 - Published: 14 April 2015

\begin{abstract}
The origin and classification of landforms denominated as "protalus ramparts" in the scientific literature is a problem that is far from being resolved. The main objective of this contribution is to support a permafrost-related definition of protalus ramparts. If we consider the Alpine framework, protalus ramparts are generally very rare landforms; by contrast, the Alpine periglacial belt is characterised by a large diffusion of talus slopes and talus rock glaciers. The investigations carried out in six sites of the Valais Alps (Switzerland) allow eight major "diagnostic criteria" to be presented that help to define protalus ramparts in Alpine environments and that support the permafrost-related genesis of most of them. The major source of controversy is related to the use of the term protalus rampart to designate both a nivo-gravitational landform (also called "pronival ramparts") and a permafrost-related landform. All the considerations presented here allow an active protalus rampart to be defined simply as a (small) active talus rock glacier.
\end{abstract}

\section{Introduction}

The origin and classification of landforms denominated as "protalus ramparts" in the scientific literature is a problem that is far from being resolved. The early works on protalus rampart were described in the late 1980s and in the early 1990 s by a series of publications by periglacial and glacial geomorphologists in several environmental and geoscientific thematic journals (e.g. Ballantyne, 1987; Barsch, 1993; Ballantyne and Benn, 1994; Shakesby et al., 1995; Hedding, 2011). The major source of controversy is related to the use of the term protalus rampart to designate both a nivo-gravitational landform and a permafrost-related landform. Under the nivo-gravitational definition, a protalus rampart (called also "pronival rampart" or "nivation ridge"; "moraine de névé" or "bourrelet-protalus" in French (cf. Pancza, 1998); "Schneehaldenmoräne" in German (cf. Barsch, 1993); and "nivomorena" in Italian (cf. Guglielmin, 1997)) is the result of a debris accumulation at the foot of a steep bedrock or scree slope of materials having slid, rolled or bounced on permanent or semi-permanent snow beds or firn fields (e.g. Shakesby, 1997; Shakesby et al., 1999; Ballantyne, 2002; Hedding et al., 2010). Under the permafrostrelated definition, on the other hand, a protalus rampart is the result of small permafrost creep phenomena in the lower part of a talus slope and can be considered as an embryonal active talus rock glacier (e.g. Barsch, 1969, 1996; Haeberli, 1985; Lambiel and Pieracci, 2008; Scapozza et al., 2011, 2015).

The main objective of this contribution is to support a permafrost-related definition of protalus ramparts. We have developed for this purpose a series of diagnostic criteria derived from investigations carried out on six protalus ramparts of the Swiss Alps. Particular emphasis will be placed on the comparison of the structure, ice content and creep dynamics of rock glaciers and talus slopes, to highlight a genesis of protalus ramparts related to the mountain permafrost creep.

\section{Investigations on protalus ramparts in the Alps}

Protalus ramparts in regional inventories of rock glaciers where these two kinds of landforms were differentiated comprise between 6 and $13 \%$, showing that the frequency of protalus ramparts in comparison to those of landforms identified as rock glacier is low. There have been inventoried, for example, 228 protalus ramparts and 1514 rock glaciers for the central Italian Alps (Scotti et al., 2013), and 13 protalus ramparts and 190 rock glaciers for the southern Swiss Alps (Scapozza and Mari, 2010). Within the framework of 


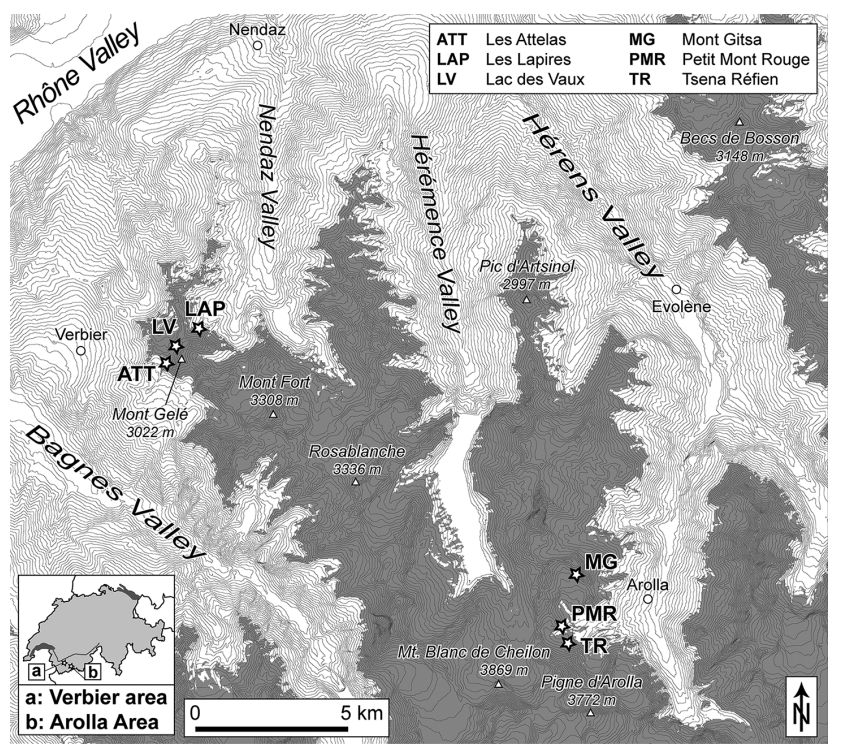

Figure 1. Location of the six protalus ramparts studied by the University of Lausanne in the Valais Alps. In grey, the potential distribution of discontinuous permafrost based on the BagnesHérémence regional model developed by Lambiel and Reynard (2001).

scientific research on the permafrost distribution and stratigraphy of talus slopes carried out at the Institute of Geography of the University of Lausanne (e.g. Lambiel, 2006; Scapozza, 2013), several investigations have concerned landforms that can be considered as protalus ramparts, in particular in six sites of the Valais Alps (Fig. 1), distributed in the Verbier (Les Attelas, Lac des Vaux and Les Lapires sites; e.g. Scapozza et al., 2010, 2011, 2015) and Arolla areas (Tsena Réfien, Mont Gitsa and Petit Mont Rouge sites; Lambiel and Pieracci, 2008; Scapozza et al., 2011; Scapozza and Laigre, 2014). These sites have always been located above the current lower limit of discontinuous permafrost, determined by a regional model of permafrost distribution based on an active/inactive rock glacier inventory (Fig. 1; for details see Lambiel and Reynard, 2001). With the exception of one site (Les Lapires talus slope, which is located at the foot of a talus but not at the foot of the entire slope), all the described protalus ramparts are located at the foot of a talus slope, where the infiltration water linked to snow melt or to rainfall can accumulate and probably facilitate the ice storage (Fig. 2).

\section{Protalus ramparts of the Swiss Alps: diagnostic criteria}

The investigations carried out at the six sites presented above allow seven major "diagnostic criteria" to be presented that help to define protalus ramparts in Alpine environments and that support the permafrost-related genesis of most of them:


Figure 2. Some protalus ramparts of the Valais Alps. (a) Les Attelas talus slope and protalus rampart, with the position of the three boreholes (B0n/08) drilled in September 2008 (photo C. Scapozza). (b) Details of the protalus rampart on the southern side of the talus slope. The dashed line depicts the front edge. (c) The Petit Mont Rouge protalus rampart, with the position of the three boreholes (B0n/09) drilled in August 2009 (photo: C. Scapozza). (d) The Lac des Vaux talus slope, with the three protalus ramparts (a, b and $\mathbf{c})$ (photo C. Scapozza).

1. During the last decennia, in all cases permanent or latelying snow fields or small firn fields were not present upstream of observed protalus ramparts.

2. Protalus ramparts most often present a bulging morphology, a very steep front $\left(40-45^{\circ}\right)$ where fine-grained material is exposed and a layer of coarse blocks on the top (Fig. 2c); this structure is not coherent with a ridge formed by debris that has slid over snow or ice patches, even if the "pronival" literature also considers other processes (e.g. Shakesby, 1997). 
3. Frequently, protalus ramparts are superimposed or juxtaposed with active/inactive or relict talus rock glaciers (sensu Barsch, 1996) (Fig. 2d).

4. Protalus ramparts are always located in areas that, according of the altitude and exposure of the slope, are potentially favourable to the presence of permafrost (Fig. 1).

5. With the exception of a protalus rampart that can be considered a (morphological) relict, all the observed landforms move downslope with a horizontal surface velocity (measured by differential GPS monitoring) ranging from a few centimetres per year to several decimetres per year (Table 1), typical of active rock glaciers.

6. The electrical resistivities and seismic wave velocities measured inside the studied protalus ramparts indicate the probable presence of permafrost (even if this does not rule out the presence of permafrost at pronival sites) (Fig. 3); these values are usually much higher than those measured in the talus slopes located upslope of the protalus ramparts (Table 2) and are very similar to those measured in active rock glaciers located in similar topoclimatic and lithological conditions, indicating that permafrost should be supersaturated with ice (for details, see the examples of the Attelas and Petit Mont Rouge protalus ramparts in Scapozza et al., 2011; Scapozza and Laigre, 2014).

7. In one case (Petit Mont Rouge protalus rampart; see Figs. 2c and 3), the presence of permafrost supersaturated with ice was demonstrated through direct investigations by well logging carried out in October 2010 in Borehole 01/09, realised in the protalus rampart in August 2009 (for details, see Scapozza et al., 2015).

8. Concerning the period of development, Scapozza (2013) highlighted by Schmidt hammer exposure-age dating (SHD) that several protalus ramparts of the Verbier and Arolla areas (Valais Alps, Switzerland) started to develop just before the mid-Holocene Climate Optimum (ca. 9.5-6.3 ka cal BP) or subsequently to that period, as was the case for the active/inactive rock glacier of the area.

This list of diagnostic criteria (deduced from field observations and geophysical prospecting and/or by the analysis and comparison of current and historical maps and aerial photographs) may allow the differentiation of protalus ramparts (considered as small active talus rock glaciers) and pronival ramparts. The differentiation is more difficult for relict features of protalus and pronival ramparts, which are morphologically similar as pointed out by Hedding (2011). Despite this point, however, it is important to underline that, in most cases, a differentiation of relict features is generally very difficult for almost all mountain glacial, nival and periglacial

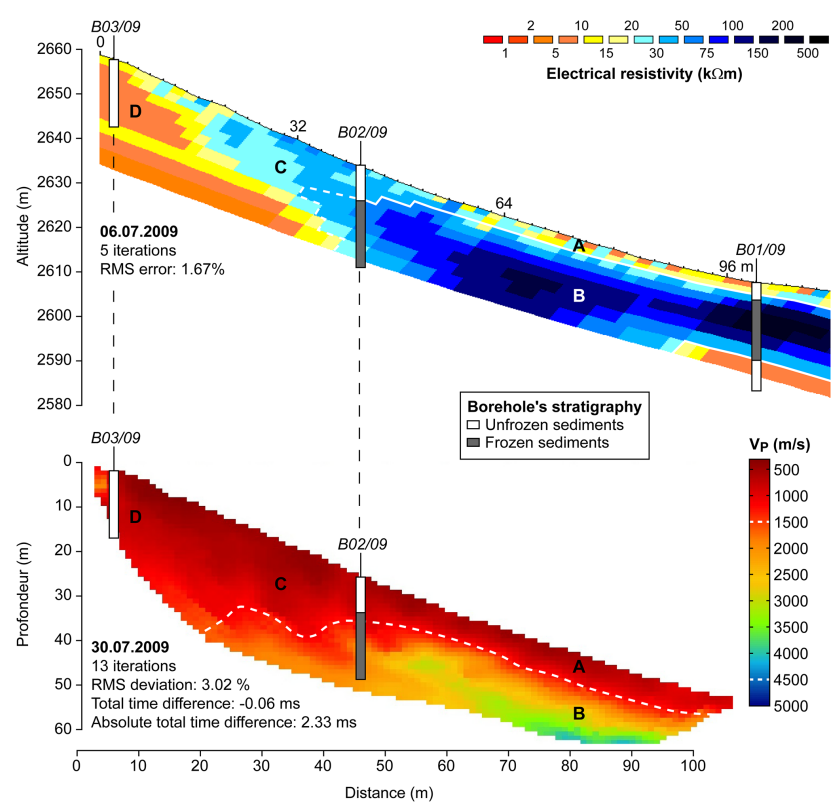

Figure 3. Comparison between an electrical resistivity tomography (ERT) profile (above) and a refraction seismic tomography (RST) profile (below) realised along the same line in July 2009 on the Petit Mont Rouge protalus rampart and talus slope (modified after Scapozza, 2013). (a) Active layer; (b) frozen body; (c) dry and porous coarse talus slope; (d) wet fine talus slope. For the location of the boreholes, see Fig. 2c.

deposits - such as between rock glaciers and deposits of glaciers that were heavily covered by debris, and between rock glaciers and push moraines - and not only between protalus ramparts and pronival ramparts.

\section{Discussion}

A major source of confusion between the different landforms designated by the term protalus rampart is probably the very different bioclimatic contexts of research between the partisans of the nivo-gravitational hypothesis and the partisans of the permafrost-related hypothesis. In the first case, the majority of studies were carried out in the British Isles and in Scandinavia (in particular in Norway), whereas in the second case many investigations were carried out in the European Alps (in particular in Switzerland), where pronival ramparts are generally very rare landforms; by contrast, the Alpine periglacial belt is characterised by a large diffusion of talus slopes and talus rock glaciers (sensu Barsch, 1996). Despite this regional difference, a supplementary source of confusion is the fact that, on the one hand, many studies on the nivo-gravitational origin of protalus ramparts that were carried out in particular in Norway may be from permafrost environments; on the other hand, permafrost is probably a characteristic of most snow bed sites. Further, "snow bed" is probably not a proper term as these features mainly con- 
Table 1. Topographical characteristics and velocity rates of the six protalus ramparts mentioned in the text.

\begin{tabular}{llllll}
\hline Code & Site & Aspect & Elevation (ma.s.1.) & Velocity rate $^{\mathrm{a}}\left(\mathrm{m} \mathrm{a}^{-1}\right)$ & Data source \\
\hline ATT & Les Attelas & W & $2620-2700$ & cm month $^{-1} \mathrm{~b}$ & Delaloye et al. (2005) \\
LAP & Les Lapires & NNE & $2610-2640$ & $0.30-1.00$ & Delaloye et al. (2010) \\
LV & Lac des Vaux B & NW & $2710-2780$ & $0.30-1.00$ & Delaloye et al. (2010) \\
MG & Mont Gitsa & SW & $2880-2940$ & No Data & - \\
PMR & Petit Mont Rouge & E & $2600-2630$ & $0.04-0.06$ & Scapozza (2013) \\
TR & Tsena Réfien & NNE & $2540-2630$ & No Data & - \\
\hline
\end{tabular}

a Order of magnitude of annual horizontal surface velocity as the mean of the entire protalus rampart.

b Order of magnitude of annual horizontal surface velocity estimated by interferometric synthetic aperture radar (InSAR) data.

Table 2. Maximal values of electrical resistivity in the permafrost body of the protalus rampart and talus slope for every research site mentioned in the text.

\begin{tabular}{llllll}
\hline Code & Site & Protalus rampart & Talus slope & Ratio & Data source \\
\hline ATT & Les Attelas & $100-150 \mathrm{k} \Omega \mathrm{m}$ & $75 \mathrm{k} \Omega \mathrm{m}$ & $1.3-2$ & Scapozza (2013) \\
LAP & Les Lapires & $15 \mathrm{k} \Omega \mathrm{m}$ & $75-100 \mathrm{k} \Omega \mathrm{m}$ & $0.15-0.2$ & Scapozza (2013) \\
LV & Lac des Vaux B & $200 \mathrm{k} \Omega \mathrm{m}$ & $10 \mathrm{k} \Omega \mathrm{m}$ & 20 & Scapozza (2013) \\
MG & Mont Gitsa & $20-40 \mathrm{k} \Omega \mathrm{m}$ & $20 \mathrm{k} \Omega \mathrm{m}$ & $1-2$ & Lambiel (2006) \\
PMR & Petit Mont Rouge & $200 \mathrm{k} \Omega \mathrm{m}$ & $100-150 \mathrm{k} \Omega \mathrm{m}$ & $1.3-2$ & Scapozza (2013) \\
TR & Tsena Réfien & $20 \mathrm{k} \Omega \mathrm{m}$ & $13-20 \mathrm{k} \Omega \mathrm{m}$ & $1-1.5$ & Lambiel (2006) \\
\hline
\end{tabular}

tain ice. For example, the site of Lyngen (Norway), studied by Ballantyne (1987), has a markedly more maritime climate than the Alps. This means that perennial snow patches can be found at higher mean annual air temperatures and are more likely to be in areas that are not conducive to having permafrost. This may explain why, in the Alps, such phenomena are rarer. Perennial snow patches are often observed in the Alps in the immediate vicinity of permafrost areas, where the remnants of snow cover suggest low or negative ground temperatures underneath (Langer and Damm, 2008).

All the diagnostic criteria listed and discussed above allow an active protalus rampart to be defined simply as a (small) active talus rock glacier, as described by Barsch (1996:224), who considered that "in most cases, 'protalus ramparts' are nothing but embryonal talus rockglaciers (active, inactive or fossil ones). They can be explained as the creep of mountain permafrost". This consideration seems to be valid even if we do not consider a very narrow or differentiated view on processes operating in high Alpine environments, which should lead us to also consider interactions between processes, for instance between periglacial and glacial/nival processes. Thus, it may very well be (although this hardly has been investigated) that protalus ramparts are influenced by both permafrost creep and nival processes. Recent results from Norway also suggest for example that use of the term "nival" is rather meaningless as many snow patches really are very old ice patches that have been stable over thousands of years (e.g. Matthews et al., 2011).

Concerning the chronology, since we do not know the exact age of protalus ramparts, it is advisable not to use the term "embryonal" rock glacier, which implies that a protalus rampart will evolve and grow over time to become a "true" rock glacier.

\section{Conclusions}

We suggest that protalus ramparts may be a typical case of interaction between different processes (in this case periglacial/glacial/nival processes) and that the lack of appreciation of these interactions have probably caused different investigators to approach this landform from either a periglacial/permafrost or a nival/glacial angle - and thus to conclude differently.

Based on a series of diagnostic criteria developed from studies on protalus rampart of the Swiss Alps, however, it is possible to conclude that their structure, ice content and creep dynamics are the same as many rock glaciers. This implies that protalus ramparts should really be a continuum of sizes (from small protalus ramparts to small rock glaciers) and thus that they are a "visible expression of steady-state creep of ice-supersaturated mountain permafrost bodies in unconsolidated materials" (Barsch, 1996:4). Protalus ramparts can then be considered, as proposed by Barsch (1996:219), as "true rockglaciers under wrong labels". Finally, to resolve the source of confusion discusses above, we propose to limit the use of the term protalus rampart, considering the nivo-gravitational framework in which this term was first "coined", and to simply call the permafrost-related phenomenon that was later also named in this way "rock glaciers". 
Acknowledgements. The $\mathrm{PhD}$ thesis of C. Scapozza was conducted at the Institute of Geography and Durability of the University of Lausanne and was supported by the Swiss National Science Foundation (SNF) (project No. 200021-119854). A special thanks to Emmanuel Reynard for his useful feedback, as well as Meredith Blake for proofreading the English.

Edited by: F. Klauser

Reviewed by: one anonymous referee

\section{References}

Ballantyne, C. K.: Some observations on the morphology and sedimentology of two active protalus ramparts, Lyngen, northern Norway, Arctic Alpine Res., 19, 167-174, 1987.

Ballantyne, C. K.: The Conachair protalus rampart, St Kilda, Scott. Geogr. J., 118, 343-350, doi:10.1080/00369220218737156, 2002.

Ballantyne, C. K. and Benn, D. I.: Glaciological constraints on protalus rampart development, Permafrost Periglac., 5, 145-153, doi:10.1002/ppp.3430050304, 1994.

Barsch, D.: Permafrost in der oberen subnivalen Stufe der Alpen, Geogr. Helv., 24, 10-12, doi:10.5194/gh-24-10-1969, 1969.

Barsch, D.: Schneehaldenmoränen (protalus ramparts), Würzburger Geographische Arbeiten, 87, 257-267, 1993.

Barsch, D.: Rockglaciers. Indicators for the present and the former geoecology in high mountain environments, Springer, Berlin Heidelberg, Germany, 331 pp., 1996.

Delaloye, R., Lambiel, C., and Lugon, R.: ESA SLAM project, phase 2, Bas-Valais. Validation of InSAR data in permafrost zone, Final Report, Bern, Federal Office of Water and Geology (FOWG), 108 pp., 2005.

Delaloye, R., Lambiel, C. and Roer, I.: Overview of rock glacier kinematics research in the Swiss Alps, Geogr. Helv., 65, 135145, doi:10.5194/gh-65-135-2010, 2010.

Guglielmin, M.: Il permafrost alpino. Concetti, morfologia e metodi di individuazione, Quaderni di geodinamica alpina e quaternaria, 5, 1-117, 1997.

Haeberli, W.: Creep of mountain permafrost: internal structure and flow of alpine rock glaciers, Mitt. Ver. Was., 77, 1-142, 1985.

Hedding, D. W.: Correspondence. Pronival rampart and protalus rampart: a review of terminology, J. Glaciol., 57, 1179-1180, 2011.

Hedding, D. W., Meiklejohn, K. I., Le Roux, J. J., Loubser, M., and Davis, J. K.: Some observations on the formation of an active pronival rampart at Grunehogna Peaks, Western Dronning Maud Land, Antarctica, Permafrost Periglac., 21, 355-361, doi:10.1002/ppp.698, 2010.

Lambiel, C.: Le pergélisol dans les terrains sédimentaires à forte déclivité: distribution, régime thermique et instabilités, $\mathrm{PhD}$ thesis, Institut de géographie, Université de Lausanne, Suisse, Travaux et recherches, 33, 260 pp., 2006.

Lambiel, C. and Pieracci, K.: Permafrost distribution in talus slopes located within the alpine periglacial belt, Swiss Alps, Permafrost Periglac., 19, 293-304, doi:10.1002/ppp.624, 2008.

Lambiel, C. and Reynard, E.: Regional modelling of present, past and future potential distribution of discontinuous permafrost based on a rock glacier inventory in the Bagnes-Hérémence area (Western Swiss Alps), Norsk Geogr. Tidsskr., 55, 210-223, doi:10.1080/00291950152746559, 2001.

Langer, M. and Damm, B.: CRYOSNOW. An approach for mapping and simulation of mountain permafrost distribution based on the spatial analyses of perennial snow patches, Geophys. Res. Abstr., 10, EGU2008-A-11263, 2008.

Matthew, J. A., Shakesby, R. A., Owen, G., and Bater A. E.: Pronival rampart formation in relation to snow-avalanche activity and Schmidt-hammer exposure-age dating (SHD): Three case studies from southern Norway, Geomorphology, 130, 280-288, doi:10.1016/j.geomorph.2011.04.010, 2011.

Pancza, A.: Les bourrelets-protalus : liens entre les éboulis et les glaciers rocheux, Permafrost Periglac., 9, 167-175, doi:10.1002/(SICI)1099-1530(199804/06)9:2<167::AIDPPP283>3.0.CO;2-L, 1998.

Scapozza, C.: Stratigraphie, morphodynamique, paléoenvironnements des terrains sédimentaires meubles à forte déclivité du domaine périglaciaire alpin, $\mathrm{PhD}$ thesis, Institut de géographie et durabilité, Université de Lausanne, Suisse, Géovisions, 40, 551 pp., 2013

Scapozza, C. and Laigre, L.: The contribution of Electrical Resistivity Tomography (ERT) in alpine dynamics geomorphology: case studies from the Swiss Alps, Geomorphologie, 1, 27-42, doi:10.4000/geomorphologie.10474, 2014.

Scapozza, C. and Mari, S.: Catasto, caratteristiche e dinamica dei rock glacier delle Alpi Ticinesi. Bollettino della Società ticinese di Scienze naturali, 98, 15-29, 2010.

Scapozza, C., Lambiel, C., Abbet, D., Delaloye, R., and Hilbich, C.: Internal structure and permafrost characteristics of the Lapires talus slope (Nendaz, Valais), 8th Swiss Geoscience Meeting 2010, Fribourg, Switzerland, 19-20 November 2010, Extended Abstract 7.16, 166-167, 2010.

Scapozza, C., Lambiel, C., Baron, L., Marescot, L., and Reynard, E.: Internal structure and permafrost distribution in two alpine periglacial talus slopes, Valais, Swiss Alps, Geomorphology, 132, 208-221, doi:10.1016/j.geomorph.2011.05.010, 2011.

Scapozza, C., Baron, L., and Lambiel, C.: Borehole logging in Alpine periglacial talus slopes (Valais, Swiss Alps), Permafrost Periglac., 26, 67-83, doi:10.1002/ppp.1832, 2015.

Scotti, R., Brardinoni, F., Alberti, S., Frattini, P., and Crosta, G. B.: A regional inventory of rock glaciers and protalus ramparts in the central Italian Alps, Geomorphology, 186, 136-149, doi:10.1016/j.geomorph.2012.12.028, 2013.

Shakesby, R. A.: Pronival (protalus) ramparts: a review of forms, processes, diagnostic criteria and palaeoenvironmental implications, Prog. Phys. Geog., 21, 394-418, doi:10.1177/030913339702100304, 1997.

Shakesby, R. A., Matthews, J. A., and McCarroll, D.: Pronival ("protalus") ramparts in the Romsdalsalpane, southern Norway: forms, terms, subnival processes, and alternative mechanisms of formation, Arctic Alpine Res., 27, 271-282, 1995.

Shakesby, R. A., Matthews, J. A., McEwen, L. J., and Berrisford, M. S.: Snow-push processes in pronival (protalus) rampart formation: geomorphological evidence from Smörbotn, Romsdalsalpane, southern Norway, Geog. Ann. A, 81, 31-45, doi:10.1111/j.0435-3676.1999.00047.x, 1999. 